\title{
SECURITY POTENTIAL OF PERSONALITY: EMPIRICAL VERIFICATION OF EVERYDAY PRACTICES AND STRATEGIES OF BEHAVIOR (ON THE EXAMPLE OF THE SOUTH OF UKRAINE)
}

\author{
Liudmyla Kalashnikova \\ $\mathrm{PhD}$ in Sociology Science, Associate Professor, \\ Petro Mohyla Black Sea National University, Ukraine \\ e-mail: lvkalashnikova198@gmail.com,orcid.org/0000-0001-9573-5955
}

\begin{abstract}
Summary
The author considers the potential of a person's safety as the basis for ensuring his life, associated with the presence of motivations, volitional qualities, dispositions to act in dangerous or extreme critical situations, not only at the level of the self-preservation instinct, but also on the basis of the inclusion of self-organizing reactions and the implementation of rational behavioral practices. The article analyzes the results of empirical research, which made it possible to verify the everyday practices and strategies for ensuring the safety of the respondents using V. Yadov's projective methodology and risk appraisal method of G. Schubert. The author found that when designing systems for safe life, almost half of the respondents choose a passive strategy of behavior. Most individuals are characterized by an active attitude of confronting or avoiding hazards. In terms of safety, almost $2 / 3$ of the respondents have inherent potential; among the active behavioral strategies for ensuring the safety of life, they make a choice in favor of event, situational or parametric behavior. Young people, in spite of their propensity to take risks, in most cases choose problem-targeted strategies of behavior.
\end{abstract}

Keywords: life safety, empirical sociological research, personality, construction of a safe life system, behavior strategies.

DOI https://doi.org/10.23856/3933

\section{Introduction}

The level of life safety is determined by both external objective factors and internal characteristics of a person, which are not equally intensely correlated with external influences and the need to secure life. The microlevel of security is regulated by existential needs, which are the basis of its reserve in situations where socially acceptable ways to achieve a safe state are not available. By that, providing the opportunity for the individual to act simultaneously as both an object and a subject of security. The personality constructs the subjective world, building a hierarchy of value priorities through the prism of awareness of the presence of threats and dangers. According to its effectiveness as a system of securing of one's own life, it completely depends on its cognitive, emotional and volitional, motivational competencies, the ability to self-organization, which make it possible to timely reveal, identify the danger, and adequately respond to it.

\section{Analysis of recent research}

O. Zotova notes that self-regulation can be viewed as a mechanism for ensuring protection against threats and dangers due to the choice of optimal personal methods of managing the situation among all available under one or another objectively subjective conditions 
of activity. Assessment of life safety through the prism of development is updated due to the fact that self-regulation is based not on adaptation to threats and dangers, but on the formation of internal resources, new personal qualities, abilities to resist them (Zotova, Zinchenko, 2010: 21-22). Sharing the reasoning of O. Zotova, T. Krasnyanska focuses on the fact that the biosocial nature of a person simultaneously contributes to and hinders self-maintenance of security. Thus, asthenic emotions, difficulties in making volitional decisions, memory limitations, violations of the communicative sphere, inadequacy of interpretation significantly violate the security potential of the personality (Krasnyanskaya, 2005: 148-149). A personality is able to manifest his or her security potential at all levels of securing of life, using it only in his or her own selfish intentions, for the good or in spite of others. According to O. Kamenska, the basis for the security potential is subjectivity - the attitude of a personality to himself or herself as a subject, which is actively acting. The leading properties of subjectivity are humanistic motivation, internal locus of control, flexible and open "Self-concept", goal-setting (Kamenskaya, 2017: 18).

Setting objectives. A subjective assessment of the security level of the living space is necessary, but insufficient, because, in addition to the level of anxiety, social well-being, mood, it is appropriate to study a person's readiness for specific actions in conditions of relative deprivation of vital needs. Therefore, based on the relevance and degree of development of the scientific topic, the purpose of this article is to analyze the results of empirical studies (a public opinion survey of residents of regional centers of the Southern region of Ukraine "Functioning of the Security Environment of the Cities in the South of Ukraine", implemented by the Mykolayiv Center of Sociological Research of Black Sea National University named after Petro Mohyla, (the term of realization - from September 24 to October 6, 2018, sample population - 801 people, sample is multi-stage, zoned, quota with non-repeatable random selection of respondents, design effect is 3.54\%); survey of students of higher educational institutions of the South of Ukraine "Risky Behavior of Student Youth" (the term of realization - December 2015 - January 2016, sample population of 409 students, multi-stage sample with non-repeatable random selection of respondents, representative by the form of ownership of the institution of higher education, location, course of study and sex of students, design effect is $4.27 \%$ ) (Meizhys, Kalashnikova, 2016), the systematization of which made it possible to carry out empirical verification of everyday practices and strategies for ensuring the security of life of these groups of respondents using the projective methodology of V. Yadov (Yadov, 1997: 84) and risk appraisal method of G. Schubert (Petrovskij, 1997).

\section{Presentation of the main research material}

According to the results of the study, it was found that $44.5 \%$ of the respondents place the responsibility for ensuring the safety of their lives on others. Citizens have rather high expectations from others: social institutions, organizations, groups, specific individuals - to whom they shift the responsibility (Table 1).

Behavioral responses to challenges and threats to life safety are expressed mainly as passivity, apathy. The use of projective questions makes it possible to determine how consciously a person perceives everything that happens to him or her, has the ability to transfer his or her life experience to projected situations. In this case, the projective methodology is focused on determining the security potential for its further correction through the development of significant competencies. 
Distribution of the respondents' answers to the question "What do you think, what, in the first place, does the securing of your life depend on?"

(\% of the total number of respondents)

\begin{tabular}{|c|c|}
\hline Answer options & \% \\
\hline Mostly on other people & 15.3 \\
\hline To some extent on me, but more on other people & 29.2 \\
\hline Equally on me and on other people & 30.1 \\
\hline More on me than on other people & 13.8 \\
\hline Mostly on me & 11.5 \\
\hline Difficult to answer & 0.1 \\
\hline
\end{tabular}

Table 2

Distribution of the respondents' answers by age to the question

"If what you fear the most happens nevertheless, how will you behave?"

( $\%$ of the total number of respondents in the social group)

\begin{tabular}{|c|c|c|c|c|c|}
\hline \multirow{2}{*}{ Answer options } & \multicolumn{5}{|c|}{ Age of respondents } \\
\cline { 2 - 6 } & $\begin{array}{c}\mathbf{1 8 - 2 9} \\
\text { years } \\
\text { old }\end{array}$ & $\begin{array}{c}\mathbf{3 0 - 3 9} \\
\text { years } \\
\text { old }\end{array}$ & $\begin{array}{c}\mathbf{4 0 - 4 9} \\
\text { years } \\
\text { old }\end{array}$ & $\begin{array}{c}\mathbf{5 0 - 5 9} \\
\text { years } \\
\text { old }\end{array}$ & $\begin{array}{c}\mathbf{6 0} \text { years old } \\
\text { and older }\end{array}$ \\
\hline $\begin{array}{c}\text { I will do everything possible and } \\
\text { impossible in order to mitigate the impact } \\
\text { of the hazard or prevent its negative } \\
\text { consequences as much as possible }\end{array}$ & 48.1 & 39.2 & 32.1 & 26.4 & 25.9 \\
\hline $\begin{array}{c}\text { I think that nothing depends on my } \\
\text { actions }\end{array}$ & 44.2 & 54.3 & 61.2 & 66.5 & 70.1 \\
\hline Difficult to answer & 7.7 & 6.5 & 6.7 & 7.1 & 4.0 \\
\hline
\end{tabular}

The majority of people in the survey express moderate fatalism, which increases with age. If in the youth cohort the number of those who are concerned $(44.2 \%)$ and those who intend to act actively (48.1\%) is almost the same, then among older people the number of those who are ready to resist dangers actively $(25.9 \%)$ is three times less than those who believe that nothing depends on them in this life $(70.1 \%)$ (Table 2$)$.

As well as self-confidence, optimistic expectations about the possibility of getting help from relatives, friends, acquaintances fade with age, and more and more hopes are pinned on the appropriate state institutions that ensure security. The number of young people aged 18-29 who are able to solve problems on their own is $19.4 \%$, while in the group of informants of 60 years old and older with the same life position, it is already three times less (Table 3 ).

Among the informants, $76.0 \%$ are ready to help civil servants in matters of securing of life, most of them are focused on collective values, expressing intentions to social actions, opposing threats to the life and health of fellow citizens (Table 4).

If we talk about specific areas of interaction aimed at preventing threats and minimizing their consequences, the majority of respondents are ready to be active, first of all, in those areas of everyday life, where they are able to exercise control. In addition, the total number of citizens for whom the forms of individual participation are acceptable (dissemination of information about obvious threats, emergencies, direct voluntary participation in the work of state bodies to ensure the safety of life on a volunteer basis) is greater than those who pin their hopes on collective events (Table 5). 
Table 3

Distribution of the respondents' answers by age to the question

"What will your first actions be in case of a real threat to your life and health?"

( $\%$ of the total number of respondents in the social group)

\begin{tabular}{|c|c|c|c|c|c|}
\hline \multirow{2}{*}{ Answer options } & \multicolumn{5}{|c|}{ Age of respondents } \\
\cline { 2 - 6 } & $\begin{array}{c}\mathbf{1 8 - 2 9} \\
\text { years } \\
\text { old }\end{array}$ & $\begin{array}{c}\mathbf{3 0 - 3 9} \\
\text { years } \\
\text { old }\end{array}$ & $\begin{array}{c}\mathbf{4 0 - 4 9} \\
\text { years } \\
\text { old }\end{array}$ & $\begin{array}{c}\mathbf{5 0 - 5 9} \\
\text { years } \\
\text { old }\end{array}$ & $\begin{array}{c}\mathbf{6 0} \text { years old } \\
\text { and older }\end{array}$ \\
\hline $\begin{array}{c}\text { I will solve the problem myself, there is } \\
\text { no other way out }\end{array}$ & 19.4 & 17.3 & 16.6 & 8.7 & 6.4 \\
\hline $\begin{array}{c}\text { I will ask for help from relatives, } \\
\text { friends, acquaintances who will be able } \\
\text { to protect me }\end{array}$ & 30.8 & 22.4 & 19.9 & 18.2 & 13.3 \\
\hline $\begin{array}{c}\text { I will contact the relevant state } \\
\text { authorities which ensure security }\end{array}$ & 48.4 & 58.8 & 61.8 & 71.1 & 74.0 \\
\hline Difficult to answer & 1.4 & 1.5 & 1.7 & 2.0 & 2.7 \\
\hline
\end{tabular}

Table 4

Distribution of the respondents' answers to the question "Are you ready to cooperate with government agencies that ensure the safety of life of the population?"

(\% of the total number of respondents)

\begin{tabular}{|c|c|}
\hline Answer options & \% \\
\hline Yes, in any situation, under any circumstances & 13.1 \\
\hline Rather yes, it all depends on the specific circumstances & 42.7 \\
\hline Yes, but on condition that the case concerns me personally & 20.2 \\
\hline Probably not, I don't want to have additional problems & 12.7 \\
\hline No, under no circumstances & 4.3 \\
\hline Difficult to answer & 6.8 \\
\hline
\end{tabular}

Table 5

Distribution of the respondents' answers to the question

"What forms of engagement in the activities of employees of state bodies that ensure life safety are most acceptable for you?" (\% of the total number of these answer options)

\begin{tabular}{|c|c|}
\hline Answer options & $\%$ \\
\hline Dissemination of information about obvious threats, emergencies & 28.1 \\
\hline Direct voluntary participation in the work of state bodies to ensure life safety on a volunteer basis & 13.6 \\
\hline Development and implementation of social projects on topical issues of urban space safety & 19.3 \\
\hline Participation in public expertise of projects on life safety & 18.5 \\
\hline Other (specify) & 3.1 \\
\hline I do not want to participate in the activities of state bodies that ensure the safety of life & 13.5 \\
\hline Difficult to answer & 3.9 \\
\hline
\end{tabular}

The situation is explained, on the one hand, by the low level of both horizontal and vertical trust, on the other hand, by the lack of confidence in one's own strengths to resist threats external to a particular person (unemployment, impoverishment, crime, environmental pollution, etc.). One of the components of the security potential of a personality is awareness 
of the activities of the state bodies, which protect security in various spheres of his or her life. The average awareness indicator is $79.4 \%$ (the sum of the arithmetic mean values of the percentages for the positions "fully informed" and "partially informed") and indicates a high level of relative primary awareness (Table 6).

Table 6

Distribution of the respondents' answers to the question "To what extent are you informed about the activities of state bodies that ensure the safety of life in such areas ...?"

(\% of the total number of respondents)

\begin{tabular}{|c|c|c|c|c|}
\hline Answer options & $\begin{array}{c}\text { Fully } \\
\text { informed }\end{array}$ & $\begin{array}{c}\text { Partially } \\
\text { informed }\end{array}$ & $\begin{array}{c}\text { Not } \\
\text { informed }\end{array}$ & $\begin{array}{c}\text { Difficult } \\
\text { to answer }\end{array}$ \\
\hline Activities of internal bodies of the state to \\
combat crime & 30.3 & 48.5 & 16.4 & 4.8 \\
\hline $\begin{array}{c}\text { Activities of internal bodies of the state to } \\
\text { counter extremism, terrorism }\end{array}$ & 44.5 & 36.6 & 8.4 & 10.5 \\
\hline $\begin{array}{c}\text { Activities of technical services to counter } \\
\text { technological and environmental disasters }\end{array}$ & 49.8 & 36.2 & 9.0 & 5.0 \\
\hline $\begin{array}{c}\text { Activities of sanitary and epidemiological } \\
\text { services to prevent the spread of morbidity of } \\
\text { the population }\end{array}$ & 35.6 & 39.4 & 17.5 & 7.5 \\
\hline $\begin{array}{c}\text { Activities of labor protection services to } \\
\text { prevent industrial injuries, violation of labor } \\
\text { legislation }\end{array}$ & 30.8 & 43.7 & 14.9 & 10.6 \\
\hline Activities of civil defense headquarters & 43.1 & 38.7 & 8.3 & 9.9 \\
\hline Activities of emergency medical services & 34.0 & 44.9 & 16.3 & 4.8 \\
\hline
\end{tabular}

However, it is worth noting that the subject of the study was not to determine the awareness of specific implemented measures, as well as their effectiveness in the light of the outstanding type of threats to the life safety of the personality.

A relatively high level of security potential is shown by $41.4 \%$ of the respondents, who are already taking all necessary measures to protect their own lives and health, another $24.1 \%$ intend to do this. More than a third of the respondents $(38.3 \%)$ take all necessary measures to protect the lives of their relatives, acquaintances, friends, and almost the same number of respondents $(30.8 \%)$ are ready to take active steps in this direction (Table 7 ).

According to the assessment of the readiness for specific actions to protect against threats, we note that every second informant tries to avoid dangerous places, every tenth respondent uses active methods of self-defense (he or she has the skills of self-defense and has means of self-defense with him or her). However, there are certain gender differences, because men consider themselves to be more protected than women (Table 8).

As you can see, the subjective level of security is actualized in the social space in the course of various forms of personality activity. Securing of his or her own life, he or she plans behavior strategies, organizes his or her desires, feelings and mind, acts actively, turning dangers into development factors.

The analysis of empirical data indicates the presence of a high level of awareness, sociability and education as the basic components of security potential, which is inherent in $2 / 3$ of the respondents. Only a third of city dwellers are capable of making situational interim decisions, acting actively for the sake of others, possessing such components as intelligence and self-organization. 
These properties of the personality as a system of securing of life are closely interrelated and can be used to substantiate the directions for improving self-regulation mechanisms.

Table 7

Distribution of the respondents' answers to the question

"What are you ready for in order to protect yourself from the most probable threats?" (\% of the total number of respondents)

\begin{tabular}{|c|c|c|c|c|}
\hline Answer options & $\begin{array}{c}\text { I am already } \\
\text { doing this }\end{array}$ & $\begin{array}{c}\text { I intend } \\
\text { to do this }\end{array}$ & $\begin{array}{c}\text { No, I am not } \\
\text { ready for } \\
\text { such actions }\end{array}$ & $\begin{array}{c}\text { Difficult to } \\
\text { answer }\end{array}$ \\
\hline $\begin{array}{c}\text { I am ready to take all necessary measures } \\
\text { to protect my own life and health }\end{array}$ & 41.4 & 24.1 & 28.0 & 6.5 \\
\hline $\begin{array}{c}\text { I am ready to take all necessary } \\
\text { measures to protect my relatives, } \\
\text { acquaintances, friends }\end{array}$ & 38.3 & 30.8 & 24.4 & 6.5 \\
\hline $\begin{array}{c}\text { I am ready to take all necessary mea- } \\
\text { sures to protect the population of the } \\
\text { city where I live }\end{array}$ & 5.3 & 22.8 & 65.3 & 6.6 \\
\hline $\begin{array}{c}\text { Not ready to act independently, but I } \\
\text { will join the "rescue team" }\end{array}$ & 8.1 & 21.0 & 64.2 & 6.7 \\
\hline $\begin{array}{c}\text { I see no reason to do something, it is } \\
\text { worth waiting until better times }\end{array}$ & 21.3 & 9.7 & 62.6 & 6.4 \\
\hline
\end{tabular}

Table 8

Distribution of the respondents' answers by gender to the question "What are you ready for in order to protect yourself from the most probable threats?" ( $\%$ of the total number of respondents in the social group)

\begin{tabular}{|c|c|c|}
\hline Answer options & Gender of respondents \\
\cline { 2 - 3 } & Men & Women \\
\hline I don't carry a lot of money with me & 15.2 & 20.4 \\
\hline I try not to leave the house unnecessarily in the dark & 16.3 & 19.1 \\
\hline I carry self-defense means with me & 11.4 & 17.4 \\
\hline I try to choose safe routes of travelling, bypassing unfavorable places & 7.5 & 15.6 \\
\hline I ask relatives and friends to meet me if I return home in the dark & 1.7 & 10.2 \\
\hline I have self-defense skills & 2.2 & 2.1 \\
\hline I feel safe, I do not use any means & 38.6 & 14.4 \\
\hline Other (specify) & 7.1 & 0.8 \\
\hline
\end{tabular}

Personal life safety is determined, on the one hand, by the ability to counteract threats and dangers, on the other hand, by the ability not to create uncertainty and to avoid it. The desire of a person to clarify this situation for himself or herself, to make it more understandable, predictable is associated with risk. After all, in the case of restriction of freedom, making a choice is actually boiled down to a special process of self-knowledge. A person's assessment of his or her own ability to implement a volitional act is a kind of attempt to test himself or herself with a risky action. Thus, the propensity to take risks (riskiness) in its positive manifestation can be considered as sub-property of security potential, as life-organization. 
As known, it is impossible to achieve absolute safety due to the high level of volatility of risks of both natural, techno- and sociogenic origin. Therefore, from the point of view of the possibility of managing the system of life safety, the interest in the study of riskiness is associated with an assessment of the individual's desire to go beyond the possible, the willingness to neglect personal safety for the sake of the collective one. Since the mastering of a culture of life safety involves the generation of non-trivial strategies of behavior in dangerous, extreme and critical situations, a balanced risk culture can be considered as its integral component.

Young people are characterized by most of the signs of risky behavior, in particular, emotional instability, self-confidence, value-normative deformations, and impaired self-regulation. This socio-demographic group is characterized by a desire for everything new and a perception of risk as a chance to achieve success. Young people reflect less than others about the possible consequences of risk, sometimes relying only on a happy providence. Risk in localized forms is one of the ways to implement the innovative resource of the younger generation.

Table 9

\section{Distribution of the respondents' answers to the question "What statement is the closest one to your life ideals?"}

(\% of the total number of respondents) (Meizhys, Kalashnikova, 2016:18)

\begin{tabular}{|c|c|}
\hline Answer options & $\mathbf{\%}$ \\
\hline Risk is the only way to be successful & 12.6 \\
\hline Taking risks means doing what you don't know & 15.3 \\
\hline There is one big risk in life - doing nothing to live better & 26.6 \\
\hline If you do not risk, you will have to be content with everyday life & 29.9 \\
\hline Risk-free people behave reasonably & 15.6 \\
\hline
\end{tabular}

Based on the results of the analysis of the data obtained, it was found that for the majority of the surveyed students, risk is an integral, normal, necessary component of life. In their view, risk is value. Thus, $56.5 \%$ of informants believe that it is practically impossible to achieve success in life without risking (Table 9).

For the sake of achieving the desired goal, more than a half of the respondents $(53 \%)$ are ready to take risks. Another part of the respondents (47\%) are not ready to take risks, not being sure of a positive end result. If to talk about what exactly students are ready to take risks, it is worth noting that the part of young people who are ready to risk everything is $18.11 \%$ of the total number of those who agree to take risks $-9.6 \%$, respectively. Most of those who agree to take risks are ready to change their permanent place of residence $(41.9 \%)$. All the rest are almost equally ready to sacrifice their career (10.7\%), their own life $(7.3 \%)$, relationships with a loved one $(6.2 \%)$, friendship $(5.7 \%)$, health $(5.6 \%)$ (Table 10$)$.

It turned out that the opinions of the respondents are diametrically opposite. Slightly more than half $(53.0 \%)$ of young people are rather self-confident, as a result, they form behavioral strategies that are inadequate to their goals, and defense mechanisms are insignificantly actualized. Most often, their riskiness is not justified. However, others are characterized by low self-esteem, as they prefer a "guaranteed success" strategy, not wanting to take risks.

From the standpoint of the individual's readiness to neglect their own safety for the sake of the collective one, which makes it possible to single out such groups of young people: those who are able to refuse from safe conditions for the sake of others $-12.1 \%$ of the respondents; those who are partially inferior to personal safety in order to achieve a specific goal $-42.5 \%$; those who 
do not allow abandonment of their own interests $-36.2 \%$; those who constantly hesitate about the choice in favor of the risk for security $-9.3 \%$. The distribution of answers by gender indicates the presence of a naturally greater propensity to risky behavior among the stronger sex. Boys are, three times more likely than girls, ready to risk their own lives, health, and family.

Table 10

\section{Distribution of the respondents' answers to the question "What are you ready to risk in order to achieve your own goals?"} (Meizhys, Kalashnikova, 2016: 18)

\begin{tabular}{|c|c|c|}
\hline Answer options & $\begin{array}{c}\text { \%o of the total number } \\
\text { of respondents }\end{array}$ & $\begin{array}{c}\text { \% of the number of those } \\
\text { who are ready to take risks }\end{array}$ \\
\hline Own life & 3.9 & 7.3 \\
\hline Health & 3.0 & 5.6 \\
\hline Well-being & 0.9 & 1.7 \\
\hline Family & 1.5 & 2.8 \\
\hline Relationship with a loved one & 3.3 & 6.2 \\
\hline Friendship & 3.0 & 5.7 \\
\hline Change of place of permanent residence & 22.2 & 10.7 \\
\hline Career & 5.7 & 18.1 \\
\hline Everything, if the risk is justified & 9.6 & - \\
\hline $\begin{array}{c}\text { Not ready to take risks, not having } \\
\text { confidence in a positive end result }\end{array}$ & 39.6 & - \\
\hline Difficult to answer & 7.4 & \\
\hline
\end{tabular}

In terms of the change in the tendencies of the propensity to take risks, we note that it weakens somewhat with age, because more adequate self-esteem, self-confidence, awareness of the need for self-affirmation are formed, this explains the difference in the responses received from respondents in the context of education courses.

$14.5 \%$ of the surveyed boys and $9.6 \%$ of girls have absolutely altruistic intentions to risk their own life and well-being for the sake of the happiness of others. The girls turned out to be more pragmatic, because they are more active than the boys, ready to take risks, hoping for success in relation to a specific result.

\section{Conclusion}

According to the results of the analysis of the data of empirical studies, it was found that, when designing systems for the safe life, almost half (44.6\%) of informants choose a passive strategy of behavior, which manifests itself in the absence of resistance, moderate fatalism, adaptation to living conditions, assigning responsibility for securing of their own lives on state and social institutions, organizations, groups of specific personalities. For $55.4 \%$ of the respondents, an active position of countering or avoiding dangers is characteristic. Security potential is inherent to almost $2 / 3$ of the respondents who, among the active behavioral strategies of securing of life, make a choice in favor of event-related, situational $(41.4 \%)$ or parametric $(24.1 \%)$ behavior. Young people, taking into account the existing propensity to take risks, in most cases choose problem-target strategies of behavior. 
As a socially active group, students show a high level of propensity to risk taking behavior. Understanding risk as a value, in most cases they are not able to fully understand all its negative consequences, which is the evidence of the low level of formation of their security potential. The modern young generation can be called "transformants-extremals", because their life is characterized by a change in social status due to the general instability of living conditions, instability of social roles, disorder of the mechanism of social identification; dangerous extreme manifestations. Not having a stable worldview, an agreed system of value orientations necessary to build a strategy for a safe life, they are in dire need of the development of special competencies, which will provide them with the opportunity to form their own socio-psychological stability and adaptive abilities necessary to secure their own lives.

\section{References}

Zotova, O. Yu., Zinchenko, Yu. P. (2010). Osnovy bezopasnosti lichnosti i obshestva [Fundamentals of personal and social security]. Moskva: Izd-vo Akademii povysheniya kvalifikacii i perepodgotovki rabotnikov obrazovaniya [in Russian].

Kamenskaya, E. (2017). Psihologicheskaya bezopasnost lichnosti i povedenie cheloveka $v$ chrezvychajnoj situacii : uchebnoe posobie [Psychological safety of the individual and human behavior in an emergency: a tutorial]. Rostov-na-Donu : Izd-vo YuFU [in Russian].

Krasnyanskaya, T. M. (2005). Lichnaya bezopasnost cheloveka v problemnom pole psihologii bezopasnosti [Personal safety of a person in the problem field of safety psychology]. Vestnik Stavropolskogo gosudarstvennogo universiteta. № 40, 145-153 [in Russian].

Meizhys, I. A., Kalashnikova, L. V. (2016). Informatsiino-analitychna dovidka: Sotsialni vymiry protsesu reformuvannia systemy osvity (na prykladi Pivdnia Ukrainy) [Information-analytical reference: Social dimensions of the process of reforming the education system (on the example of the South of Ukraine)]. Mykolaiv: Vydavnytstvo ChDU im. P. Mohyly [in Ukraine].

Petrovskij, V. A. (1997). Neadaptivnyj risk: fenomenologiya i opyt interpretacii [Non-adaptive risk: phenomenology and experience of interpretation]. Upravlenie riskom. № 3, 29-34.

Yadov, V. A. (1997). Struktura i pobuditelnye impulsy socialno-trevozhnogo soznaniya [Structure and incentive impulses of socially anxious consciousness]. Sociologicheskij zhurnal. № 3, 77-91. 